\title{
Chemotaxonomic significance of flavonoids, coumarins and triterpenes of Augusta longifolia (Spreng.) Rehder, Rubiaceae-Ixoroideae, with new insights about its systematic position within the family
}

\author{
Rafael Choze, ${ }^{1}$ Piero G. Delprete, ${ }^{2}$ Luciano M. Lião ${ }^{*, 1}$
}

\begin{abstract}
${ }^{1}$ Instituto de Química, Universidade Federal de Goiás, Campus Samambaia, 74001-970 Goiania-GO, Brazil, ${ }_{2}^{2}$ Institut de Recherche pour le Développement - AMAP, TA-A51/PS2, Blvd de la Lironde, 34398 Montpellier Cedex 5, France.
\end{abstract}

\begin{abstract}
RESUMO: "Significância quimiotaxômica de flavonoides, cumarinas e triterpenos de Augusta longifolia (Spreng.) Rehder, Rubiaceae- Ixoroideae, com novos entendimentos sobre a posição sistemática dentro da família". Augusta tem sido tradicionalmente colocada na tribo Rondeletieae, Cinchonoideae subfamília. No entanto, recentes filogenias moleculares posicionou-a perto de Wendlandia, porém localizando $A$. longifolia perto do clado Ixoroidinae II. O estudo de $A$. longifolia resultou em duas cumarinas, cinco flavonoides, três triterpenoides e um derivado do ácido benzóico. Estes metabolitos reforçam a separação da Augusta como um gênero monoespecífico, e Lindenia como um gênero de três espécies, intimamente relacionada com Wendlandia.
\end{abstract}

Unitermos: Rubiaceae, Augusta, Wendlandia, Lindenia, quimiotaxonomia.

\begin{abstract}
Augusta has traditionally been placed in the tribe Rondeletieae, subfamily Cinchonoideae. However, recent molecular phylogenies positioned it near to Wendlandia (Ixoroideae), but locate $A$. longifolia near to the clade Ixoroidinae II. The study of $A$. longifolia afforded two coumarins, five flavonoids, three triterpenoids and one benzoic acid derivative. These metabolites reinforce the separation of Augusta as a monospecific genus, and Lindenia as a genus of three species, closely related to Wendlandia.
\end{abstract}

Keywords: Rubiaceae, Augusta, Wendlandia, Lindenia, Chemotaxonomy.

\section{INTRODUCTION}

The family Rubiaceae is composed by about 650 genera and 13,000 species, and represented by herbs, shrubs, trees, and lianas, mostly of tropical and subtropical distribution (Delprete, 2004). The family is currently divided into three subfamilies: Rubioideae, Cinchonoideae, and Rubioideae (Bremer et al., 1995; Rova et al., 2002; Delprete, 2004).

According to the delimitations by Kirkbride (1997) and Delprete (1997), Augusta (including Lindenia) is a genus of four species of rheophytic shrubs of puzzling geographic distribution: 1) A. longifolia Pohl, endemic to Brazil, 2) A. rivalis (Benth.) J.H. Kirkbr., endemic to Central America, 3) A. austrocaledonica (Brongn.) J.H. Kirkbr., endemic to New Caledonia, and 4) A. vitiensis (Seem.) J.H. Kirkbr., endemic to the Fiji Islands. Also, Kirkbride divided Augusta into two subgenera: Subgen. Augusta, containing only A. longifolia, with narrowlycampanulate, red flowers, and subgen. Lindenia, containing the other three species, with long-tubular, white flowers. Augusta has traditionally been placed in the tribe Rondeletieae, in the subfamily Cinchonoideae (Robbrecht, 1988; Delprete, 1997). However recent molecular phylogenies have positioned it in subfamily Ixoroideae. Aside from its systematic position within the family, the phylogenies of Rova et al. (2002) supported the delimitation of Augusta proposed by Kirkbride and Delprete, even though only two species of Augusta and one of Wendlandia were included in the study (Delprete, 1997). Wendlandia is a genus of about 50-70 species occurring in the Indo-Malaysian Region, that has never been subject of a taxonomic revision, and its monophyly has never been tested. Both have capsular fruits with minute, winddispersed seeds, facilitating dispersals among distant areas, and supporting the unusual geographic distribution of these genera.

Recently, Robbrecht \& Manen (2006) presented molecular phylogenies using DNA sequences of four regions of the plastid genome, rbcL, rps16, trnL-F and 
atpB-rbcL, with the intent of producing a new family classification. In their study, the general tree topology resembled that of the three-subfamily system (e.g., Bremer et al., 1995; Rova et al., 2002), but the authors preferred to divide the Rubiaceae into two subfamilies and several supertribes. In the phylogenies of Robbrecht \& Manen (2006), the position and delimitation of Augusta was not the same as those of Rova et al. (2002): "Lindenia was found as sister taxon to Wendlandia, based on the trnL-F source, while Augusta is sister taxon to the clade Ixoroidinae II in the atpB-rbcL spacer tree (Robbrecht \& Manen, 2006). These results contrast with the reduction of Lindenia as a subgenus of Augusta proposed by Kirkbride (1997), and the authors placed the Wendlandia and Lindenia as part of the Wendlandia/Augusta informal group, while they kept Augusta as tentatively included in it.

Saad et al.(1988) were able to isolate two iridoid alkaloids, lindenialine and lindeniamine, from Lindenia austrocaledonica Brongn. (=Augusta austrocaledonica), this being the only report of compounds isolated from Augusta as broadly delimited. Glycosidic iridoids were isolated from the leaves of Wendlandia formosana Cowan by Takeda et al. (1977) in the form of gardenoside, methyl deacetylasperulosidate, tarennoside and geniposidic acid, as well as 10-O-caffeoyl scandoside methyl, 10-O-caffeoyl daphylloside and 6-methoxy scandoside methyl ester isolated by Raju et al. (2004). Scandoside methyl ester was isolated from the wood of W. bicuspidata Wight \& Arn. by De Silva et al. (1986), and geniposidic acid from the stem of W. tinctoria (Roxb.) DC. by Dinda et al. (2004).

The main objective of the present study was isolate compounds that might be used as taxonomic markers to help elucidate the systematic position and generic delimitation of the Augusta-Lindenia-Wendlandia complex.

\section{MATERIALS AND METHODS}

\section{General procedures}

Chromatographic separations in adsorption column were carried out using Merck silica gel (70-230 and 230-400 mesh ASTM, Merck), and Sephadex LH-20 (Aldrich). TLC were produced using Merck silica gel 60 $\mathrm{F}_{254}$, and revealed by ultraviolet radiation at $\lambda=254 \mathrm{~nm}$ and $366 \mathrm{~nm}$, followed by nebulization with $\mathrm{H}_{2} \mathrm{SO}_{4}$ /anisaldehyde/ acetic acid (1:0.5:50) solution, and subsequently heated.

The ${ }^{1} \mathrm{H}$ and ${ }^{13} \mathrm{C}$ NMR spectra were recorded on a Bruker DRX 400 and on a Varian Unit Plus spectrometers at 400 and $100 \mathrm{MHz}$, respectively, using the appropriate deutered solvent and TMS as internal reference. The GC/MS analysis was performed on Shimadzu QP5050A instrument employing the following conditions: column DB-5 (Shimadzu), fused silica capillary column, $30 \mathrm{~m} \mathrm{x}$ $0.25 \mathrm{~mm}, 0.25 \mu \mathrm{m}$ film thickness, temperature gradient of $4{ }^{\circ} \mathrm{C} / \mathrm{min}$ from $60^{\circ} \mathrm{C}$ to $295^{\circ} \mathrm{C}$. The carrier gas was helium at 8 psi pressure; injector port and detector temperature were $250{ }^{\circ} \mathrm{C}$ and $200{ }^{\circ} \mathrm{C}$, respectively. Samples were injected by splitting and the split ratio 1:50. The infrared spectroscopy were obtained with a Bomem FTIR, model MB-100, using $\mathrm{KBr}$ tablets.

\section{Plant material}

Delprete (1997) recognized two varieties of Augusta longifolia: var. longifolia, occurring in the cerrado biome and var. parvifolia (Pohl.) Delprete, restricted to the Atlantic forest of the Rio de Janeiro State.

Plant material of Augusta longifolia var. longifolia was collected by P.G. Delprete and R. Choze in Mossâmedes, Goiás State, Brazil (S 1604', W 50¹1', 500 $\mathrm{m})$, from natural populations growing at the margins and among rocks inside the Córrego Piçarrão, a small creek at the base of the Serra Dourada reserve, in December 2005. The material was identified by Delprete, and voucher specimens (collection N. 9442-A) were deposited at the herbarium of the Universidade Federal de Goiás, Goiânia, Brazil.

\section{EXTRACTION AND ISOLATION OF CONSTITUENTS}

Dried and powdered stem barks of $A$. longifolia $(400 \mathrm{~g})$ were extracted with EtOH. The resulting EtOH extract was filtered and concentrated in vacuo to afford a brown gum (20.1 g), which was submitted to liquid-liquid partitioning. The $n$-hexane, ethyl acetate and butanol soluble parts of the EtOH extract were concentrated in vacuo affording 4.8, 5.2 and $6.1 \mathrm{~g}$, respectively. The ethyl acetate fraction was submitted to a silica gel column (70230 mesh) eluted with a $\mathrm{CHCl}_{3} / \mathrm{EtOAc} / \mathrm{MeOH}$ gradient, yielding three fractions. The chloroform fraction was submitted to a silica gel column (70-230 mesh) eluted with $\mathrm{CHCl}_{3} / \mathrm{EtOAc}(65 / 35)$ yielding the esterified triterpenes

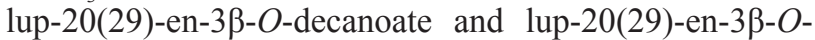
dodecanoate $(25 \mathrm{mg})$. The EtOAc fraction was submitted to a flash silica gel CC (230-400 mesh), eluted with a $\mathrm{CHCl}_{3} /$ $\mathrm{MeOH}$. The fraction 2 was then purified by preparative TLC (silica gel, $\mathrm{CH}_{2} \mathrm{Cl}_{2} / \mathrm{MeOH}, 70 / 30$ ) yielding coumarin $(6.5 \mathrm{mg})$. Fraction 3 was also purified by preparative TLC (silica gel, $\mathrm{CH}_{2} \mathrm{Cl}_{2} /$ acetone/MeOH, 60/30/10), affording the coumarin scopoletin $(4.0 \mathrm{mg})$ and 2-methoxy-4hydroxy-benzoic acid $(5.0 \mathrm{mg})$. The methanolic fraction was silica gel chromatographed (70-230 mesh) using acetone $/ \mathrm{MeOH}$ in gradient form resulting nine fractions. The fraction 5 afforded the flavonoid naringenin $(2.5 \mathrm{mg})$. Fraction 7 was then chromatographed by a flash silica gel CC (230-400 mesh), eluted with acetone/MeOH (15/85), yielding the flavonoids kaempferol $(6.0 \mathrm{mg})$ and quercetin (4.5 mg). The butanol fraction was first chromatographed by sephadex $\mathrm{LH}-20$, eluted with $\mathrm{H}_{2} \mathrm{O} / \mathrm{MeOH}(1 / 1)$ and then submitted to silica gel CC (70-230 mesh), eluted with 
organic phase of $\mathrm{CHCl}_{3} / \mathrm{MeOH} / \mathrm{H}_{2} \mathrm{O}(5 / 5 / 3)+5 \% \mathrm{MeOH}$, affording the flavonol myricitrin $(155.0 \mathrm{mg})$.

Dried and powdered leaves of $A$. longifolia $(800$ g) were extracted with EtOH. The resulting EtOH extract was filtered and concentrated in vacuo to afford a $14.1 \mathrm{~g}$ of crude extract. This extract was silica gel chromatographed affording the hexane $(9.7 \mathrm{~g})$, ethyl acetate $(2.1 \mathrm{~g})$ and methanol $(0.4 \mathrm{~g})$ fractions. The methanol fraction was submitted to a silica gel (70-230 mesh), using $\mathrm{CHCl}_{3}$ ' $\mathrm{MeOH} / \mathrm{H}_{2} \mathrm{O}(5 / 5 / 3)+10 \% \mathrm{MeOH}$, affording seven fractions. The fraction 3 was then flash chromatographed on silica gel (230-400 mesh), eluting with organic phase of $\mathrm{CHCl}_{3} / \mathrm{MeOH} /$ butanol $/ \mathrm{H}_{2} \mathrm{O}(6 / 5 / 1 / 3)+6 \% \mathrm{MeOH}$, affording the flavonol rutin $(7.0 \mathrm{mg})$. The hexanic fraction after silica gel $\mathrm{CC}$ (70-230 mesh), eluted with $\mathrm{CHCl}_{3}$ / acetone afforded the trieterpene ursolic acid $(20.0 \mathrm{mg})$.

Dried and powdered woods of A. longifolia (150 g) were extracted with EtOH. The resulting EtOH extract was filtered and concentrated in vacuo to afford a $5.0 \mathrm{~g}$ of crude extract. This extract was silica gel chromatographed (70-230 mesh) using hexane, acetone and methanol in gradient form. The fraction acetone was submitted to a silica gel $\mathrm{CC}$ (70-230 mesh), eluted with a $\mathrm{CH}_{2} \mathrm{Cl}_{2}$ /acetone in gradient form, resulting eight fractions. The fraction 2 was then flash chromatographed on silica gel (230-400 mesh), eluted with $\mathrm{CHCl}_{3} / \mathrm{MeOH}$ (15/85), affording 2-methoxy-4hydroxy-benzoic acid $(7 \mathrm{mg})$. The methanolic fraction was chromatographed on a silica gel column (230-400 mesh), eluted with organic phase of $\mathrm{CHCl}_{3} / \mathrm{MeOH} / \mathrm{H}_{2} \mathrm{O}(2 / 5 / 1)+$ $20 \% \mathrm{MeOH}$, obtaining large quantities of myricitrin.

\section{RESULTS}

In this paper we report the isolation of eleven known compounds from Augusta longifolia (Spreng.) Rehder var. longifolia. The compounds were identified by IR, GC/MS, ${ }^{1} \mathrm{H}$ and ${ }^{13} \mathrm{C}$ NMR one and two-dimensional techniques, and their structural propose were confirmed by literature data. From stem bark were isolated two pentacyclic triterpenes acyl lupeols (1 and 2, $25 \mathrm{mg}$, Brum et al., 1998); two coumarins, coumarin (3, $6.5 \mathrm{mg}$, Tonin \& Tavares, 2002) and scopoletin (4, $4.0 \mathrm{mg}$, Silva et al., 2002); four flavonoids, naringenin $(5,2.5 \mathrm{mg}$, Almeida et al., 2005), kaempferol (6, 6 mg, Oliveira et al., 1999), quercetin (7, 4.5 mg, Barberá, 1986; Agrawal \& Bansal, 1989) and myricitrin $(9,155.0 \mathrm{mg}$, Timbola et al., 2002), besides 2-methoxy-4-hydroxy-benzoic acid (11, $12 \mathrm{mg}$, Scott, 1972). From the leaves were isolated the flavonoid rutin (8, 7 mg, Buszewski et al., 1993; Agrawal \& Bansal, 1989) and a pentacyclic triterpene ursolic acid (10, $20 \mathrm{mg}$, Tkachev et al., 2004). The compounds 9 and 11 were also isolated from the woods. No iridoids were found in the leaves and steam barks of $A$. longifolia.

\section{DISCUSSION}

\section{Terpenes}

In this specie were isolated the pentacyclic triterpenes ursolic acid (10) from the leaves, and two acyl lupeols (1 and $\mathbf{2}$ ) from the stem bark. The abundance and

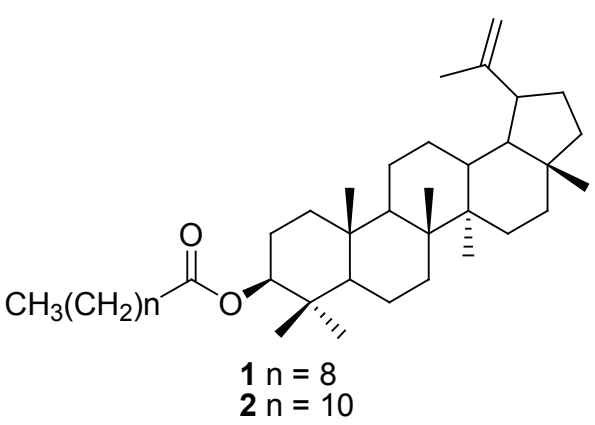<smiles>[R]c1cc(-c2oc3cc(O)cc(O)c3c(=O)c2[R])cc([R3])c1O</smiles>

$6 \mathrm{R}_{1}=\mathrm{OH} ; \mathrm{R}_{2}=\mathrm{H} ; \mathrm{R}_{3}=\mathrm{H}$

$7 \mathrm{R}_{1}=\mathrm{OH} ; \mathrm{R}_{2}=\mathrm{H} ; \mathrm{R}_{3}=\mathrm{OH}$

$8 \mathrm{R}_{1}=$ OGly-Ram; $\mathrm{R}_{2}=\mathrm{H} ; \mathrm{R}_{3}=\mathrm{OH}$

$9 \mathrm{R}_{1}=\mathrm{ORam} ; \mathrm{R}_{2}=\mathrm{OH} ; \mathrm{R}_{3}=\mathrm{OH}$<smiles>[R]c1cc2ccc(=O)oc2cc1[R]</smiles>

$3 \mathrm{R}_{1}=\mathrm{R}_{2}=\mathrm{H}$

$4 \mathrm{R}_{1} \mathrm{OMe} ; \mathrm{R}_{2}=\mathrm{OH}$<smiles>C[C@H]1CC[C@]2(C(=O)O)CC[C@]3(C)C(=CCC4[C@@]5(C)CC[C@@H](O)C(C)(C)C5CC[C@]43C)C2[C@@H]1C</smiles>

10<smiles>O=C1CC(c2ccc(O)cc2)Oc2cc(O)cc(O)c21</smiles>

5<smiles>COc1cc(O)ccc1C(=O)O</smiles>

11 
frequency of these compounds in Rubiaceae has been reported from many species of the three subfamilies (Delprete et al., 2006). The ursolic acid triterpene and the diterpene phytol were also isolated from Wendlandia formosana Cowan (Raju et al., 2004); however the universal presence of this compound in the family shows no taxonomic significance.

\section{Coumarins}

The compound coumarin (3), a simple coumarin, was the first time reported in Rubiaceae. Its biosynthesis is simple and rather rare in the Angiosperms. This compound has been commonly isolated in species of Fabaceae and Asteraceae, as in Amburana cearensis (Allemão) A.C. Sm. (Fabaceae; Canuto \& Silveira, 2006), and in Mikania Willd. (Asteraceae; Dos Santos, 2005). A study focusing on the evolutionary trends in coumarin-producing Angiosperm families, reports the occurrence of 91 simple coumarins in the order Gentianales, of which 59 in the Rubiaceae, 21 in the Apocynaceae, 4 in the Menyanthaceae, 2 in the Gentianaceae, 3 in the Asclepiadaceae, and 2 in the Loganiaceae (Ribeiro \& Kaplan, 2002). A. longifolia also afforded scopoletin (4), which belongs to the subclass of hydroxy-coumarins. This compound was isolated in many genera of the Rubiaceae, mainly in the subfamily Ixoroideae, as this studied specie.

\section{Flavonoids}

In $A$. longifolia were isolated the flavonoids: naringenin (5), kaempferol (6), quercetin (7) from stem bark, myricitrin from steam bark and woods (9) and rutin (8) from the leaves. Myrictrin was also isolated from the wood. These findings are in agreement with the biochemical survey conducted by Delprete et al. (2006), where the subfamily Ixoroideae was characterized by the moderate presence of flavonoids, where flavonols are in majority. Special attention should be given to the flavonol myricitrin (9), which is also reported the first time in the Rubiaceae. This glycosilated flavonol was also found in the fruits of Pouteria Aubl. (Sapotaceae; Ma et al., 2004) and of Manilkara zapota (L.) P. Royen (Sapotaceae; Ma et al., 2003). In addition, it was also isolated in the leaves Eugenia L. (Myrtaceae; Schmeda-Hirschmannet et al., 1987) and in the latex of Croton draco Schltdl. (Euphorbiaceae; Tsacheva et al., 1987).

\section{Benzoic acid derivates}

2-Methoxy-4-hydroxy-benzoic acid (11) was isolated, and it is present in many taxa of the three subfamilies of the Rubiaceae. This compound has a great structural similarity with salicylic acid, a benzoic acid derivate with pharmacologic importance (Berretta, 2007). Therefore, for possessing a similar bioactive nucleus, this benzoic acid derivate might also have similar biological properties; however, this remains to be tested.

\section{Iridoids}

Despite many attempts, no iridoids were found in A. longifolia. On the other hand, in Wendlandia and Lindenia were isolated glycosidic and alkaloidic iridoids, respectively. From the leaves of Wendlandia formosana were isolated gardenoside, 10-O-caffeoyl scandoside methyl ester, 10-O-caffeoyl daphylloside, 6-methoxy scandoside methyl ester, methyl deacetylasperulosidate, tarennoside and geniposidic acid (all glycosidic iridoids; Takeda et al., 1977; Raju et al., 2004); while scandoside methyl ester was found in the wood of $W$. bicuspidata Wight \& Arn. (De Silva et al., 1986), and geniposidic acid in the stem of $W$. tinctoria (Roxb.) DC. (Dinda et al., 2004). In addition, two alkaloidic iridoids, lindenialine and lindeniamine, were isolated from the leaves of Lindenia austrocaledonica Brongn. (Saad et al., 1988).

\section{Taxonomic significance}

The presence or absence of certain compounds in Augusta longifolia supplied several taxonomic markers with valuable information about the systematic position of this species within the Rubiaceae. The isolation of flavonoids and coumarins in Augusta, not isolated at the moment in Lindenia or Wendlandia, suggests the chemical uniqueness of this species in the family and in the order Gentianales. On the other hand, glycosidic and alkaloidic iridoids were obtained in Wendlandia and Lindenia, and no iridoids were yet found in Augusta, suggesting that Augusta, could be treated as a monospecific genus, and is not closely related to Lindenia (as traditionally defined) and Wendlandia. Therefore, the results of this study reinforce the systematic position and the generic circumscriptions of the three genera as indicated in the atpB-rbcL spacer phylogeny of Robbrecht \& Manen (2006, fig. 3).

\section{ACKNOWLEDGMENT}

The authors are grateful to CAPES and FUNAPE for scholarships and financial support, as well as to Dr. Antonio Gilberto Ferreira, Departamento de QuímicaUFSCar, for NMR spectra.

\section{REFERENCES}

Agrawal PK, Bansal MC 1989. Carbon-13 NMR of flavonoids. Elsevier: New York.

Almeida SCX, Lemos TLG, Silveira ER, Pessoas ODL 2005. Constituintes voláteis e não voláteis de Cochlospermum vitifolium. Quim Nova 28: 57-60.

Barberá O, Sanz JF, Sánchez-Parareda J, Marco JA 1986. Further flavonol glycosides from Anthyllis onobrychioides. 
Phytochemistry 25: 2361-2365.

Berretta AA 2007. Fitoterapia como prática integrativa e complementar no SUS. II Semana Farmacêutica do HC. Ribeirão Preto, Brasil.

Bremer B, Andreasen K, Olsson D 1995. Subfamilial and tribal relationships in the Rubiaceae based on $\mathrm{rbcL}$ sequence data. Ann Missouri Bot Gard 82: 383-397.

Brum RL, Honda NK, Cavalheiro AJ, Monache FD 1998. Acyl lupeols from Cnidoscolus vitifolius. Phytochemistry 19:1127-1128.

Buszewski B, Kawka S, Suprynowicz Z, Wolski TJ 1993. Simultaneous isolation of rutin and esculin from plant material and drugs using solid-phase extraction. $J$ Pharmaceut Biomed 11: 211-215.

Canuto KM, Silveira ER 2006. Constituintes químicos da casca do caule de Amburana cearensis A.C. Smith. Quim Nova 29: 1-3.

Delprete PG 1997. Revision and typification of Brazilian Augusta (Rubiaceae, Rondeletieae), with ecological observation on riverine vegetation of Cerrado and Atlantic Forest. Brittonia 49: 487-497.

Delprete PG 2004. Rubiaceae. In: Smith, N.P. et al. (Eds.). Flowering Plant Families of the American Tropics. Princeton University Press, New York, p. 328-333.

Delprete PG, Choze R, Silva RA, Dufrayer CR 2006. Abstracts of the 3rd International Rubiaceae Conference, K.U. Leuven, Belgium.

De Silva LB, Herath WHMW, Malangani Navaratne K, Ahmad VU, Alvi KA 1986. An iridoid glycoside from Wendlandia bicuspidata. J Nat Prod 50: 1184-1184.

Dinda B, Debnath S, Arima S, Sato N, Harigaya Y 2004. Chemical constituents of Lasia spinosa, Mussaenda incana and Wendlandia tinctoria. J Indian Chem Soc 81: 73-76.

Dos Santos SC 2005. Caracterização cromatográfica de extratos medicinais de Guaco: Mikania laevigata Schultz Bip. ex Baker e M. glomerata Sprengel e ação de M. laevigata na inflamação alérgica pulmonar. Itajaí, 120p. Dissertação de Mestrado - Programa de Pós-graduação em Ciências Farmacêuticas, Universidade do Vale do Itajaí, SC, Brazil.

Kirkbride JH 1997. Manipulus rubiacearum VI. Brittonia 49: 354-379.

Ma J, Luo XD, Protiva P, Yang H, Ma C, Basile MJ, Weinstein IB, Kennelly EJ 2003. Bioactive novel polyphenols from the fruit of Manilkara zapota (Sapodilla). J Nat Prod 66: 983-986.

Ma J, Yang H, Basile MJ, Kennelly EJ 2004. Analysis of polyphenolic antioxidants from the fruits of three Pouteria species by selected ion monitoring liquid chromatography-mass spectrometry. J Agric Food Chem 52: 5873-5878.

Oliveira MCC, Carvalho MG, Ferreira DT, Braz-Filho R 1999. Flavonóides das flores de Stiffitia chrysantha Mikan. Quim Nova 22: 182-185.

Raju BL, Lin S, Hou W, Lai Z, Liu P, Hsu F 2004. Antioxidant iridoid glucosides from Wendlandia formosana. Nat Prod
Res 18: 357-364.

Ribeiro CVC, Kaplan MAC 2002. Tendências evolutivas de famílias produtoras de cumarinas em angiospermas. Quim Nova 25: 533-538.

Robbrecht E 1988. Tropical woody Rubiaceae. Characteristic features and progressions. Contributions to a new subfamilial classification. Opera Bot Belg 1: 1-271.

Robbrecht E, Manen JF 2006. The major evolutionary lineages of the coffee family (Rubiaceae, angiosperms). Combined analysis (nDNA and cpDNA) to infer the position of Coptospelta and Luculia, and supertree construction based on rbcL, rps16, trnL-trnF and atpB-rbcL data. A new classification in two subfamilies, Cinchonoideae and Rubioideae. Syst Geogr Pl 76: 85-146.

Rova JHE, Delprete PG, Andersson L, Albert VA 2002. A trnL-F cpDNA sequence study of the CondamineaeRondeletieae-Sipaneeae complex with implications on the phylogeny of the Rubiaceae. Am J Bot 89: 145-159.

Saad HEA, Aanton R, Quirion JC, Chauvière G, Pusset J 1988. New-caledonian plants. 116 (1). Lindenialine and lindeniamine, two new iridoids from Lindenia austrocaledonica Brongn. Tetrahedron Lett 29: 615-618.

Schmeda-Hirschmann G, Theoduloz C, Franco L, Ferro E, Arias AR 1987. Preliminary pharmacological studies on Eugenia uniflora leaves: xanthine oxidase inhibitory activity. J Ethnopharmacol 21: 183-186.

Scott KN 1972. Carbon-13 Nuclear Magnetic Resonance of Biologically important aromatic acids.I. Chemical shifts of benzoic acid and derivatives. J Am Chem 94: 85648568.

Silva WPK, Deraniyagala SA, Wijesundera RLC, Karunanayake EH, Priyanka UMS 2002. Isolation of scopoletin from leaves of Hevea brasiliensis and the effect of scopoletin on pathogens of $H$. brasiliensis. Mycopathologia 153: 199-202.

Takeda Y, Nishimura H, Inouye H 1977. Iridoid glucosides of Wendlandia formosana. Phytochemistry 16: 1300-1301.

Timbola AK, Szpoganicz B, Branco A, Monache FD, Pizzolatti $\mathrm{MG}$ 2002. A new flavonol from leaves of Eugenia jambolana. Fitoterapia 73: 174-176.

Tkachev AV, Denisov AY, Gatiloov YV, Bagryanskaya IY, Shevtsov SA, Rybalova TV 2004. Triterpenes and triterpenoidal glycosides from the fruits of Ilex paraguariensis. J Braz Chem Soc 15: 205-211.

Tonin FG, Tavares MFM 2002. Otimização de extração de cumarina em folhas de Mikania laevigata para uso fitoterápico. Simpósio de Plantas Medicinais, Cuiabá.

Tsacheva I, Rostan J, Iossifova T, Vogler B, Odjakova M, Navas H, Kostova I, Kojouharova M, Kraus W 1987. Complement inhibiting properties of dragon's blood from Croton draco. Z Naturforsch 59: 528-532. 